\title{
Hypersaline tidal flats as important "blue carbon" systems: a case study from three ecosystems
}

\author{
Dylan R. Brown ${ }^{1}$, Humberto Marotta ${ }^{2,3,4}$, Roberta B. Peixoto ${ }^{2,3}$, Alex Enrich-Prast ${ }^{2,5,6}$, Glenda C. Barroso ${ }^{3}$, \\ Mario L. G. Soares ${ }^{7}$, Wilson Machado ${ }^{3}$, Alexander Pérez $z^{3,8}$, Joseph M. Smoak ${ }^{9}$, Luciana M. Sanders ${ }^{10}$, \\ Stephen Conrad $^{1}$, James Z. Sippo ${ }^{1,10,11}$, Isaac R. Santos ${ }^{1,12}$, Damien T. Maher ${ }^{1,10,11}$, and Christian J. Sanders ${ }^{1,13}$ \\ ${ }^{1}$ National Marine Science Centre, School of Environment, Science and Engineering, Southern Cross University, \\ P.O. Box 4321, Coffs Harbour, NSW, 2450, Australia \\ ${ }^{2}$ Ecosystems and Global Change Laboratory (LEMG-UFF), International Laboratory of Global Change \\ (LINCGlobal), Biomass and Water Management Research Center (NAB), Universidade Federal Fluminense, \\ Av. Edmundo March, s/n extdegree, Niterói, RJ, 24210-310, Brazil \\ ${ }^{3}$ Graduate Program in Geosciences (Environmental Geochemistry), Department of Geochemistry, Universidade Federal \\ Fluminense, Niterói, RJ, 24020-141, Brazil \\ ${ }^{4}$ Physical Geography Laboratory (LAGEF-UFF), Department of Geography, Graduate Program in Geography, Universidade \\ Federal Fluminense, Av. Gal. Milton Tavares de Souza, s/no., Niterói, RJ, 24210-346, Brazil \\ ${ }^{5}$ Department of Thematic Studies - Environmental Change, Linköping University, 581 83, Linköping, Sweden \\ ${ }^{6}$ Department of Botany, Universidade Federal do Rio de Janeiro, Rio de Janeiro, RJ, 21941-902, Brazil \\ ${ }^{7}$ Laboratory For Mangrove Studies (NEMA-UERJ), International Laboratory of Global Change (LINCGlobal) and \\ Interdisciplinary Observatory on Climate Change (OIMC-UERJ), Department of Biological Oceanography, \\ Faculty of Oceanography, Universidade do Estado do Rio de Janeiro (UERJ), Rua São Francisco Xavier, \\ 524, sala 4019-E, Rio de Janeiro, RJ, 20550-900, Brazil \\ ${ }^{8}$ Laboratorio de Biogeociencias, Laboratorios de Investigación y Desarrollo (LID), Facultad de Ciencias y Filosofía, Centro \\ de Investigación para el Desarrollo Integral y Sostenible (CIDIS), Universidad Peruana Cayetano Heredia, Av. Honorio \\ Delgado 430, Urb. Ingeniería, Lima, Peru. \\ ${ }^{9}$ School of Geosciences, University of South Florida, St. Petersburg, FL 33701, USA \\ ${ }^{10}$ Southern Cross GeoScience, Southern Cross University, P.O. Box 157, Lismore, NSW, 2480, Australia \\ ${ }^{11}$ School of Environment, Science and Engineering, Southern Cross University, P.O. Box 157, Lismore, NSW, 2480, Australia \\ ${ }^{12}$ Department of Marine Sciences, University of Gothenburg, Gothenburg, Sweden \\ ${ }^{13}$ State Key Laboratory of Estuarine and Coastal Research, East China Normal University, Shanghai 201100, P.R. China
}

Correspondence: Christian Sanders (christian.sanders@scu.edu.au) and Dylan Brown (d.brown.34@student.scu.edu.au)

Received: 16 November 2020 - Discussion started: 24 November 2020

Revised: 11 February 2021 - Accepted: 16 February 2021 - Published: 22 April 2021

\begin{abstract}
Hypersaline tidal flats (HTFs) are coastal ecosystems with freshwater deficits often occurring in arid or semiarid regions near mangrove supratidal zones with no major fluvial contributions. Here, we estimate that organic carbon (OC), total nitrogen (TN) and total phosphorus (TP) were buried at rates averaging $21( \pm 6), 1.7( \pm 0.3)$ and 1.4 $( \pm 0.3) \mathrm{g} \mathrm{m}^{-2} \mathrm{yr}^{-1}$, respectively, during the previous century in three contrasting HTF systems, one in Brazil (eutrophic) and two in Australia (oligotrophic). Although these rates are
\end{abstract}

lower than those from nearby mangrove, saltmarsh and seagrass systems, the importance of HTFs as sinks for OC, TN and TP may be significant given their extensive coverage. Despite the measured short-term variability between net airsaltpan $\mathrm{CO}_{2}$ influx and emission estimates found during the dry and wet season in the Brazilian HTF, the only site with seasonal $\mathrm{CO}_{2}$ flux measurements, the OC sedimentary profiles over several decades suggest efficient $\mathrm{OC}$ burial at all sites. Indeed, the stable isotopes of $\mathrm{OC}$ and $\mathrm{TN}\left(\delta^{13} \mathrm{C}\right.$ and 
$\delta^{15} \mathrm{~N}$ ) along with $\mathrm{C}: \mathrm{N}$ ratios show that microphytobenthos are the major source of the buried OC in these HTFs. Our findings highlight a previously unquantified carbon as well as a nutrient sink and suggest that coastal HTF ecosystems could be included in the emerging blue carbon framework.

\section{Introduction}

Hypersaline tidal flats (HTFs), supratidal flats, saltpans, sabkhas and salt flats are all terms used to define the shallow coastal ecosystems on the upper fringe of fluviomarine plains in estuaries showing freshwater deficits (Ridd and Stieglitz, 2002; Albuquerque et al., 2014). These environments are generally located in an intermediary position between mangrove forests or saltmarshes and the terrestrial environment and are common in many tropical arid, and to a lesser extent non-arid, intertidal zones. These systems occur in many regions around the world including northern Australia, Africa, Spain, the Gulf of Mexico and throughout Brazil where they are referred to as apicum ecosystems (Ridd and Stieglitz, 2002; Albuquerque et al., 2013, 2014; Soares et al., 2017). In arid and semi-arid estuaries (Ridd and Stieglitz, 2002) or humid tropical supratidal zones with less fluvial contribution (Soares et al., 2017), HTF ecosystems cover an area that exceeds mangrove forests and occupy a substantial proportion of tropical intertidal zones. HTFs occupy the area just below the highest astronomical tides and are thus only flooded for short periods of the year (Ridd and Stieglitz, 2002; Bento et al., 2017). Evaporation, the flat topography and pronounced hydraulic deficit results in hypersaline conditions with salinity as high as 5 times that of seawater (Ridd and Stieglitz, 2002; Shen et al., 2018).

Despite the extreme conditions and the apparent absence of vegetation, microphytobenthos are commonly found on the surface of HTFs (usually in the form of microbial mats dominated by cyanobacteria from the Oscillatoriales order including Microcoleus spp., Leptolyngbya spp. and Lyngbya sp.) (Adame et al., 2012; Masuda and Enrich-Prast, 2016). These microphytobenthos are well adapted to the extreme conditions (Paerl et al., 2000) and are considered to be the main primary producers in HTFs. Similarly to traditional vegetated blue carbon systems (Ouyang and Lee, 2014; Sanders et al., 2016a; Macreadie et al., 2019; Serrano et al., 2019), these microphytobenthos are capable of high rates of carbon $(\mathrm{C})$ and nitrogen $(\mathrm{N})$ fixation from the atmosphere, particularly after periods of flooding and/or rainfall (Chairi et al., 2010; Adame et al., 2012; Burford et al., 2016). Their ability to sequester and potentially store carbon and nutrients in their soils for long periods of time (centuries to millennia) makes them noteworthy contenders to be included in the blue carbon framework (Lovelock and Duarte, 2019). Upon inundation, the fixed $\mathrm{C}, \mathrm{N}$ and other nutrients such as phosphorus (P) may be leached from the microbial mats and transported to adjacent coastal areas, where nutrient subsidies can enhance the overall productivity of the receiving ecosystems (Adame et al., 2012; Burford et al., 2016).

Given the few studies on HTFs, there is limited understanding of the role that these ecosystems play in the coastal zone and whether they are currently under threat from global change (Halpern et al., 2008; Martinez-Porchas and Martinez-Cordova, 2012). To date, there has been large-scale destruction and degradation of these systems on a global scale as a result of anthropogenic pressures on coastal areas including infilling for urban and agricultural development (Halpern et al., 2008). Although there has been the implementation of various laws in some parts of the world to prevent the loss of coastal vegetated systems, this legislation rarely extends to protect HTFs that are viewed as being ecological deserts with no obvious vegetation (Albuquerque et al., 2013). Furthermore, the landward encroachment of mangrove forests as a response to rising sea levels, coupled to barriers preventing landward migration of HTFs (i.e. the "coastal squeeze"), may also contribute to the loss of these ecosystems (Alongi, 2008; Saintilan et al., 2014; Kelleway et al., 2017).

Given the substantial areal extent of these HTFs and the fact that they remain relatively undisturbed in many regions around the world, HTFs may have unrecognised ecological values (Burford et al., 2016). However, information on OC, nitrogen and phosphorus burial, and sediment $\mathrm{CO}_{2}$ fluxes from these ecosystems remains scarce (e.g. Bento et al., 2017; Schile et al., 2017). Determining if HTFs are a source or sink of carbon is critical to understanding their importance and value in regards to climate change and coastal carbon sequestration (Lovelock and Duarte, 2019). Here, we quantify carbon and nutrient burial and atmospheric $\mathrm{CO}_{2}$ fluxes in HTFs in Australia and Brazil. We hypothesise that microphytobenthos in HTFs sequester $\mathrm{CO}_{2}$ from the atmosphere and a portion of this organic matter (and associated nitrogen and phosphorus) is buried, similarly to the traditional vegetated blue carbon systems.

\section{Methods}

\subsection{Study site}

This study was conducted in three tropical HTFs in Australia and Brazil (Fig. 1). In Australia, the HTF study sites were located near Karumba, Queensland $\left(17^{\circ} 25^{\prime} 12^{\prime \prime} \mathrm{S}\right.$, $140^{\circ} 51^{\prime} 36^{\prime \prime} \mathrm{E}$ ), and Curtis Island, Gladstone, Queensland (Site $1-23^{\circ} 45^{\prime} 41^{\prime \prime} \mathrm{S}, 151^{\circ} 16^{\prime} 34^{\prime \prime} \mathrm{E}$; Site $2-23^{\circ} 45^{\prime} 18^{\prime \prime} \mathrm{S}$, $\left.151^{\circ} 16^{\prime} 49^{\prime \prime} \mathrm{E}\right)$, and in Brazil the study site was located in Guaratiba, Rio de Janeiro ( $\left.23^{\circ} 00^{\prime} 29^{\prime \prime} \mathrm{S}, 43^{\circ} 36^{\prime} 31^{\prime \prime} \mathrm{W}\right)$.

In Australia, the Karumba HTF is located adjacently to the oligotrophic mouth of the Norman River estuary on the southeastern coast of the Gulf of Carpentaria. The study site consists of a large continuous HTF $\left(16.9 \mathrm{~km}^{2}\right)$ in the high up- 


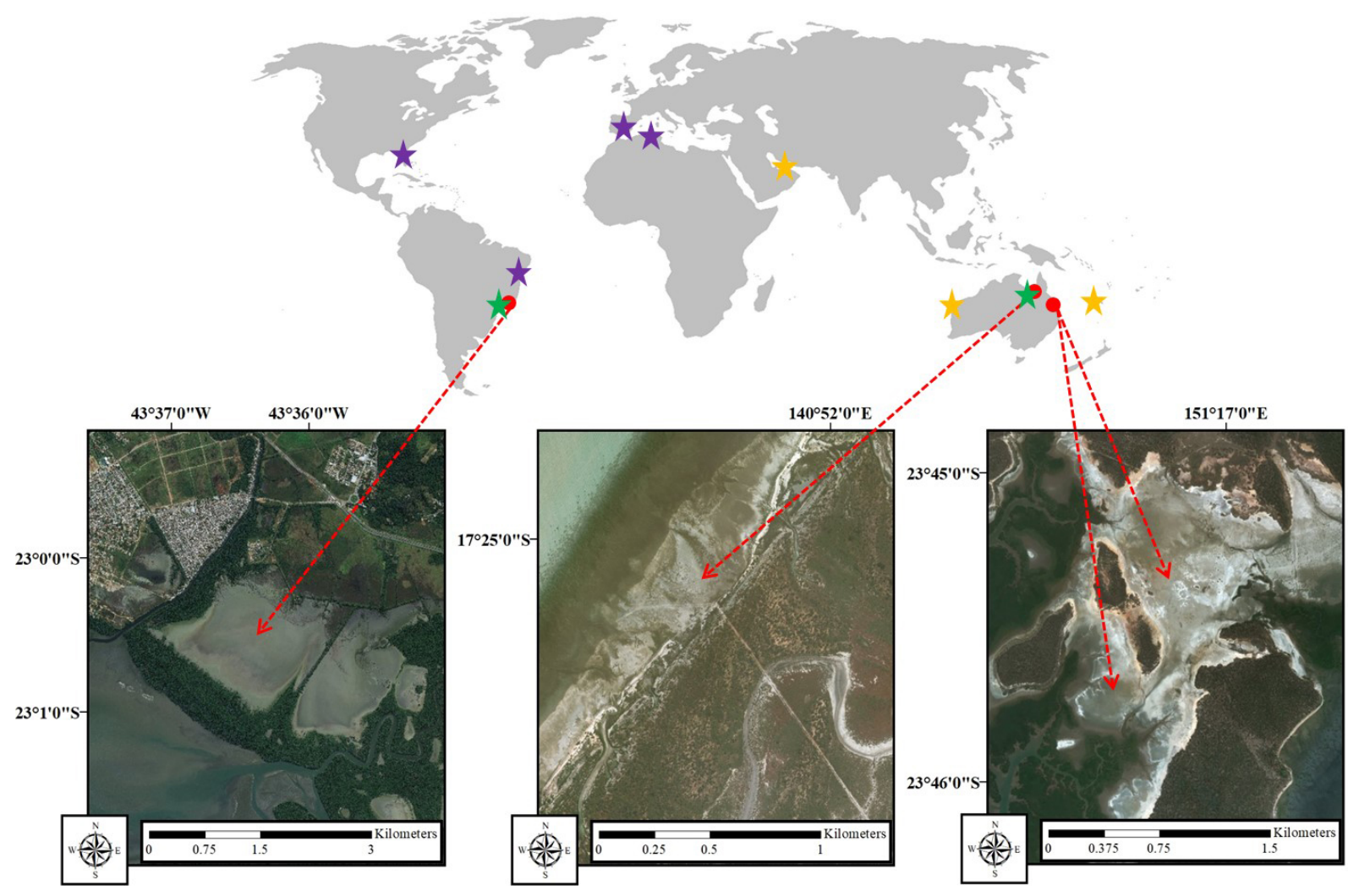

Figure 1. Study sites (red arrows): Guaratiba, Brazil (left); Karumba, Australia (centre); and Gladstone, Australia (right). Stars show the location of literature data summarised in Table 3. Purple stars are areas with only sediment carbon content data, green stars are areas with only gas flux data, and yellow stars are areas with both sediment carbon content and gas flux data from hypersaline tidal flat (HTF) studies (satellite images were taken from @Google Earth).

per intertidal zone. The southeastern Gulf of Carpentaria has a diurnal tidal cycle (typical range $<0.1-4.5 \mathrm{~m}$ ) and a 23year average annual rainfall of $833 \mathrm{~mm}$ (based on monthly averages from 1938 to 2010) with most falling in the summer monsoon period (790 $\mathrm{mm}$ from December to March) $(\mathrm{Bu}-$ reau of Meteorology, 2019). The 19-year average maximum monthly temperatures (from 1993 to 2019) vary from $27^{\circ} \mathrm{C}$ in the dry winter months to $33^{\circ} \mathrm{C}$ in the wet summer months (Bureau of Meteorology 2019). A narrow strip of mangrove forest followed by extensive tidal mudflats fringes the HTFs on the seaward side.

Gladstone Harbour experiences similar tidal and climatic conditions to Karumba with semidiurnal tides (typical range $0.1-4.7 \mathrm{~m}$ ) and a 25-year average annual rainfall of $846 \mathrm{~mm}$ (based on monthly averages from 1994 to 2019), with most also falling in the summer monsoon period $(537 \mathrm{~mm}$ from December to March) (Bureau of Meteorology, 2019). The 26-year average maximum monthly temperatures (from 1993 to 2019) vary from 23 in the winter months to $31^{\circ} \mathrm{C}$ in the summer months (Bureau of Meteorology, 2019). The sheltered strait between Curtis Island and the mainland of Australia is largely occupied by mangrove forests and large continuous expanses of HTFs. The Gladstone site contained two
HTF study areas; Site $1\left(2.84 \mathrm{~km}^{2}\right)$ was situated in the higher tidal area and was inundated less frequently and for shorter periods of time than Site $2\left(0.95 \mathrm{~km}^{2}\right)$.

In Brazil, the tropical HTF was located in the Guaratiba State Biological Reserve, $\sim 40 \mathrm{~km}$ south of the city of Rio de Janeiro which forms part of the Sepetiba Bay estuary system. This conservation area is surrounded by the urban expansion area of the city of Rio de Janeiro, and Sepetiba Bay receives discharges of nutrients and organic matter from its watershed dominated by agriculture, pasture and urban uses (Rezende et al., 2010). The HTF covers an area of approximately $7.4 \mathrm{~km}^{2}$, equivalent to almost $36 \%$ of the fringing mangrove forest (Estrada et al., 2013; Soares et al., 2017) (Table 1). There is little variation in topography, and the tidal range is 0.1$2.0 \mathrm{~m}$ (Masuda and Enrich-Prast, 2016; Bento et al., 2017). The 32-year monthly average rainfall and temperature vary from $36 \mathrm{~mm}$ and $21^{\circ} \mathrm{C}$ in dry winter months to $138 \mathrm{~mm}$ and $27^{\circ} \mathrm{C}$ in rainy summer months, reaching an annual average of accumulated rainfall of $1058 \mathrm{~mm}$ (Estevam, 2019) (Table 1). 
Table 1. Characterisation of study sites. Rainfall $(\mathrm{mm})$ and temperature $\left({ }^{\circ} \mathrm{C}\right)$ data are based on annual averages derived from monthly measurements ( $n$ is number of years of data), and HTF : mangrove area indicates the ratio of hypersaline tidal flat area to mangrove area.

\begin{tabular}{lllll}
\hline & \multicolumn{4}{c}{ Hypersaline tidal flat study sites } \\
\cline { 2 - 5 } & Guaratiba & Karumba & $\begin{array}{l}\text { Gladstone Site 1, } \\
\text { high tidal area }\end{array}$ & $\begin{array}{l}\text { Gladstone Site 2, } \\
\text { low tidal area }\end{array}$ \\
\hline Location & $23^{\circ} 00^{\prime} 29^{\prime \prime} \mathrm{S}$, & $17^{\circ} 25^{\prime} 12^{\prime \prime} \mathrm{S}$, & $23^{\circ} 45^{\prime} 41^{\prime \prime} \mathrm{S}$, & $23^{\circ} 45^{\prime} 18^{\prime \prime} \mathrm{S}$, \\
Rainfall $(\mathrm{mm})$ & $43^{\circ} 36^{\prime} 31^{\prime \prime} \mathrm{W}$ & $140^{\circ} 51^{\prime} 36^{\prime \prime} \mathrm{E}$ & $151^{\circ} 16^{\prime} 34^{\prime \prime} \mathrm{E}$ & $151^{\circ} 16^{\prime} 49^{\prime \prime} \mathrm{E}$ \\
Temperature $\left({ }^{\circ} \mathrm{C}\right)$ & $1058(n=32)$ & $883(n=23)$ & $846(n=25)$ & $846(n=25)$ \\
Tidal range $(\mathrm{m})$ & $21-27(n=32)$ & $27-33(n=19)$ & $23-31(n=26)$ & $23-31(n=26)$ \\
HTF area $\left(\mathrm{km}^{2}\right)$ & $0.1-2.0$ & $0.1-4.5$ & $0.1-4.7$ & $0.1-4.7$ \\
HTF : mangrove area & $1: 4$ & 16.9 & 2.84 & 0.95 \\
\hline
\end{tabular}

\subsection{Sediment core sampling and analysis}

Sediment cores (one core per site for a total of four cores) were collected from the middle of HTFs either by using a $50 \mathrm{~cm}$ long, $5 \mathrm{~cm}$ diameter Russian peat auger (Karumba core) or by inserting a PVC tube $(8.7 \mathrm{~cm}$ diameter) into the substratum using manual percussion (Gladstone and Guaratiba cores). Only cores with no observed compaction were retained for further analysis. The sediment cores were sectioned at $1 \mathrm{~cm}$ intervals (with the exception of the Karumba core which was sectioned at $2 \mathrm{~cm}$ intervals). Dry bulk density (DBD; $\mathrm{g} \mathrm{cm}^{-3}$ ) was determined as the dry sediment weight (g) divided by the initial volume $\left(\mathrm{cm}^{3}\right)$ (Ravichandran et al., 1995). From the original dry section, a non-homogenised portion was rewetted and treated with $30 \%$ hydrogen peroxide $\left(\mathrm{H}_{2} \mathrm{O}_{2}\right)$ to remove organic matter without altering grain size. A solution of sodium hexametaphosphate was used as a deflocculating agent to separate aggregates prior to grain size analysis. Grain size analyses were conducted using a CILAS 1090L diffraction laser unit or wet sieving following the methods used by Conrad et al. (2019). Total phosphorous (TP) was measured after acid digestion $\left(\mathrm{H}_{2} \mathrm{O}: \mathrm{HF}: \mathrm{HClO}_{4}\right.$ : $\left.\mathrm{HNO}_{3}, 2: 2: 1: 1\right)$ using a Perkin Elmer ELAN DRC-e ICPMS.

Organic carbon (OC) and total nitrogen (TN) stable isotope ratios of mangrove leaves, microphytobenthos and HTF sediments were measured to identify the sources of organic matter $(\mathrm{OM})$ contributing to the sediment column at each site. Fresh green leaves from mangrove trees $(n=3$ for each dominant species: Rhizophora mangle, Avicenna shaueriana and Laguncularia racemosa) were collected at 1-2 m above the soil and washed with deionised water soon after sampling in the Brazilian HTF. Samples were then lyophilised, crushed and sieved, and $\sim 6-8 \mathrm{mg}$ was encapsulated in tin capsules to determine the $\mathrm{OC}, \mathrm{TN}$ and their isotopic composition $\left(\delta^{13} \mathrm{C}\right.$ and $\left.\delta^{15} \mathrm{~N}\right)$. Microphytobenthos samples, in the form of dense algal mats, were collected from the surface of HTF sediments, scrapped and thoroughly washed with deionised water to avoid sediment contamination. A total of six microphytobenthos samples were collected and analysed (three from Brazil, two from Karumba and one from Gladstone). A homogenised portion was acidified to remove carbonate material, washed in deionised water, dried $\left(60^{\circ} \mathrm{C}\right)$, and then ground to powder for $\mathrm{OC}$ and $\delta^{13} \mathrm{C}$ analyses using a Leco Flash Elemental Analyzer coupled to a Thermo Fisher Delta V IRMS (isotope ratio mass spectrometer). A non-acidified homogenised portion was also analysed for TN and $\delta^{15} \mathrm{~N}$. Analytical precision was as follows: $\mathrm{C}=0.1 \%$, $\mathrm{N}=0.1 \%, \delta^{13} \mathrm{C}=0.1 \%$ and $\delta^{15} \mathrm{~N}=0.15 \%$. We assess whether HTFs accumulate carbon and then compare HTFs with well-established, nearby mangrove systems.

Radionuclides from the uranium-238 $\left({ }^{238} \mathrm{U}\right)$ decay series were measured in high-purity germanium (HPGe) gamma detectors, a planar for the Gladstone and Guaratiba and a well detector for the Karumba samples. Identical geometry was used for all samples, and sample dry weights were between 20 and $30 \mathrm{~g}$. Sealed and packed samples were set aside for at least $21 \mathrm{~d}$ to allow for radon-222 $\left({ }^{222} \mathrm{Rn}\right)$ ingrowth and to establish secular equilibrium between radium-226 $\left({ }^{226} \mathrm{Ra}\right)$ and its granddaughter lead-214 $\left({ }^{214} \mathrm{~Pb}\right)$. Lead-210 $\left({ }^{210} \mathrm{~Pb}\right)$ activity was determined by the direct measurement of the $46.5 \mathrm{KeV}$ gamma peak. The ${ }^{226} \mathrm{Ra}$ activity was determined via the ${ }^{214} \mathrm{~Pb}$ daughter at $351.9 \mathrm{KeV}$. The ${ }^{210} \mathrm{~Pb}$ and ${ }^{226} \mathrm{Ra}$ activities were calculated by multiplying the counts per minute by a correction factor that includes the gamma-ray intensity and detector efficiency determined from NIST Rocky Flats soils reference material. Excess ${ }^{210} \mathrm{~Pb}$ was used to determine ages of sediment intervals using the constant initial concentration (CIC) model (Appleby and Oldfield, 1992). Mass accumulation rates were multiplied by the percent of OC, $\mathrm{N}$ and TP to calculate burial rates.

\subsection{Air-sediment gas flux measurements}

$\mathrm{CO}_{2}$ fluxes at the air-sediment interface were measured in July 2009 and 2010 and February 2015 (Guaratiba, Brazil), August 2016 and 2018 (Karumba, Australia), and June 2018 (Gladstone, Australia), encompassing the annual variation in 
emissions between dry and rainy seasons in the HTF in Brazil and non-monsoon months in Australia. In all sampling sites, we used sediment chambers connected in a closed system with an infrared or cavity ring-down analyser as reported in Lovelock (2008). The sediment chambers were composed of transparent plexiglass (light chamber) or an opaque material such as PVC or covered by layers of aluminium foil (dark chamber) for measurements of light and dark air-sediment $\mathrm{CO}_{2}$ fluxes, respectively (Leopold et al., 2015). Before each measurement, the chambers were gently pushed into the sediment $(\sim 2 \mathrm{~cm})$ to form a gas-tight seal. Each short-term incubation lasted 5-15 min to achieve a linear change in $\mathrm{CO}_{2}$ concentration within the chambers and was associated with a maximum increased temperature of $\sim 2{ }^{\circ} \mathrm{C}$ in relation to external conditions, indicating no bias due to warming and subsequent changes in the inner pressure and biological activity. Gas concentrations were measured using either a Los Gatos Research (LGR) Ultraportable Greenhouse Gas Analyzer (UGGA) or a Picarro G4301 GasScouter recorded at $1 \mathrm{~s}$ intervals in the Australian sites and using either a PP Systems EGM-4 or a Vaisala GMT222 at 1 min intervals in the Brazilian sites. Equipment had been previously calibrated with $\mathrm{CO}_{2}$ standards of 400 and 1000 ppm in the laboratory.

$\mathrm{CO}_{2}$ fluxes were measured in dark and light conditions in Brazil ( $n=51$ and 94, respectively) and Australian ( $n=46$ and 32, respectively) HTFs. The air-sediment $\mathrm{CO}_{2}$ fluxes were calculated from the maximum linear change in $\mathrm{CO}_{2}$ concentration over the duration of the measurement using the following formula (Rosentreter et al., 2017, and references therein):

$F=\left(s\left(V / R T_{\text {air }}\right)\right) A$

where $s$ is the regression slope for each chamber incubation deployment $\left(\mathrm{ppm} \mathrm{s}^{-1}\right.$ or $\mathrm{ppm} \mathrm{min}^{-1}$, converted to $\mathrm{ppm}^{-1}$ ), $V$ is the chamber volume $\left(\mathrm{m}^{3}\right), R$ is the universal gas constant, $T_{\text {air }}$ is the air temperature inside the chamber $(\mathrm{K})$ and $A$ is the surface area of sediment inside the chamber $\left(\mathrm{m}^{2}\right)$. Negative values represent net sediment $\mathrm{CO}_{2}$ uptake, while positive ones represent net $\mathrm{CO}_{2}$ emission from sediments to the atmosphere. We assume that pressure in the chamber is $1 \mathrm{~atm}$. To determine the net ecosystem exchange (NEE), we integrate diurnal and night fluxes from light and dark chambers for each sampling day, respectively. To test the normality of $\mathrm{CO}_{2}$ emissions data, we performed a KolmogorovSmirnov test. For non-normally distributed data, a MannWhitney test (significance level $p<0.05$ ) was undertaken to compare light and dark fluxes at the combined Brazil and Australian samples and also to compare wet and dry season Brazil fluxes.

\section{Results}

\subsection{Sediment accretion rates (SARs)}

All four sediment profiles showed a net down-core decrease in excess ${ }^{210} \mathrm{~Pb}$ activity reaching background levels at the bottom of each sediment core (Fig. 2), enabling the use of the CIC ${ }^{210} \mathrm{~Pb}$ dating methodology. All cores were dated back to between 50 and 110 years with constant sediment accretion rates estimated at $0.11 \pm 0.05$ (1903), $0.18 \pm 0.06$ (1955), $0.21 \pm 0.05$ (1931) and $0.23 \pm 0.05 \mathrm{~cm} \mathrm{yr}^{-1}$ (1964) for Guaratiba, Karumba, Gladstone Site 1 and Gladstone Site 2 HTF sediment cores, respectively.

\subsection{Carbon, nitrogen and phosphorus burial rate estimates}

Most of the parameters remained relatively constant throughout the sediment profiles, with no clear vertical trends in grain size, OC, TN or TP (Fig. 3). Sand content was generally $<20 \%$, and $\mathrm{OC}$, TN and TP contents ranged from $0.09 \%$ to $1.40 \%, 0.01 \%$ to $0.16 \%$ and $0.02 \%$ to $0.12 \%$, respectively, across all sites and depth intervals (Fig. 3). By multiplying the average sedimentation rate, DBD and OC content in these cores, we obtained carbon burial rates of 17.8 $( \pm 0.8), 31.7( \pm 4.3), 11.3( \pm 2.1)$ and $25.2( \pm 2.9) \mathrm{g} \mathrm{m}^{-2} \mathrm{yr}^{-1}$ in the Guaratiba, Karumba, Gladstone Site 1 and Gladstone Site 2 cores, respectively, for the past $\sim 50$ years (Table 2). Average TN burial rates were $2.3( \pm 0.2), 2.8$ $( \pm 0.3), 0.8( \pm 0.1)$ and $1.2( \pm 0.1) \mathrm{g} \mathrm{m}^{-2} \mathrm{yr}^{-1}$, and average TP burial rates were $2.0( \pm 0.1), 1.3( \pm 0.1), 1.4( \pm 0.0)$ and $1.4( \pm 0.3) \mathrm{g} \mathrm{m}^{-2} \mathrm{yr}^{-1}$ in the Guaratiba, Karumba, Gladstone Site 1 and Gladstone Site 2 cores, respectively (Table 2).

\subsection{Organic matter source}

To assess the source of organic matter (OM), sediment, HTF microphytobenthos and nearby mangrove endmember samples were analysed for $\delta^{13} \mathrm{C}$ stable isotopes and cross-plotted against molar $\mathrm{C}: \mathrm{N}$ ratios (Fig. 4). Microphytobenthos samples showed a small spread in $\delta^{13} \mathrm{C}$ and molar $\mathrm{C}: \mathrm{N}$ ratios ranging from $-13.4 \%$ to $-19.0 \%$ and $7.9 \%$ to $14.8 \%$, respectively (Fig. 4). Similarly, values of $\delta^{13} \mathrm{C}$ and molar C : N ratios showed little down-core variation in both the Guaratiba $(-17.7 \%$ to $-18.4 \%$ and $7.6 \%$ to $9.7 \%$, respectively) and Karumba ( $-15.5 \%$ to $-20.5 \%$ and $10.5 \%$ o to $14.6 \%$, respectively) sediment cores. In contrast, both the Gladstone sediment cores showed a considerable range in the $\delta^{13} \mathrm{C}$ and molar $\mathrm{C}: \mathrm{N}$ values $(-20.1 \%$ o to $-24.2 \%$ and $13.6 \%$ o to $21.8 \%$ at Site $1,-16.6 \%$ to $-24.4 \%$ and 10.7 to 34.8 at Site 2). Higher $\delta^{15} \mathrm{~N}$ and lower $\mathrm{C}: \mathrm{N}$ ratio values were noted in the Guaratiba HTF compared to other sites (Fig. 4). 

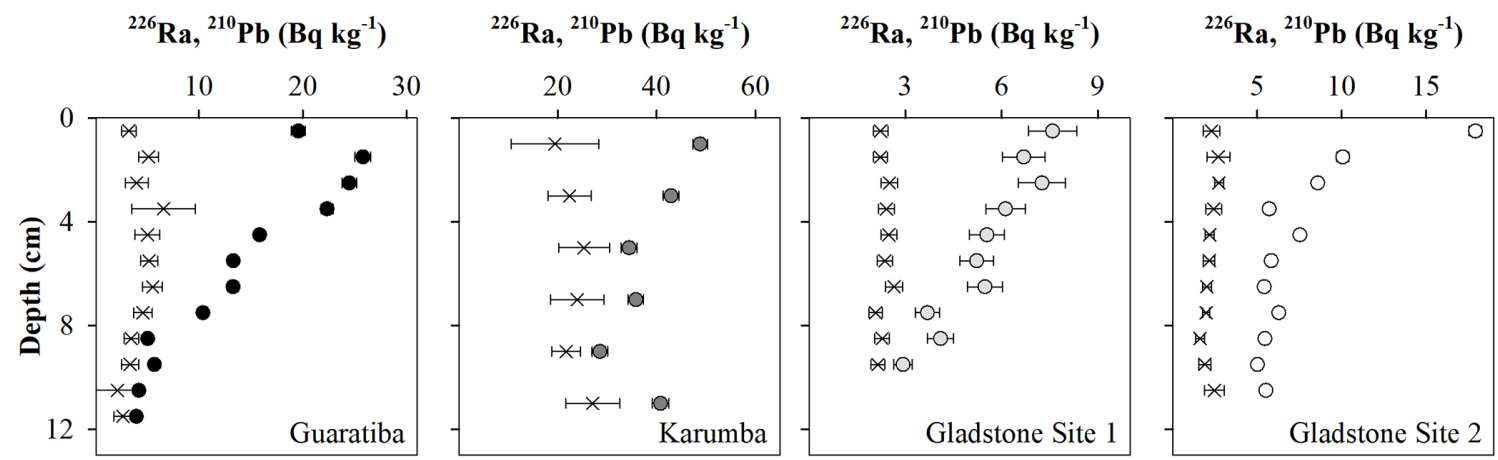

Figure 2. The ${ }^{226} \mathrm{Ra}(\times)$ and ${ }^{210} \mathrm{~Pb}$ (circles) depth profiles of the four hypersaline tidal flat sediment cores in this work. Error bars indicate counting uncertainties.
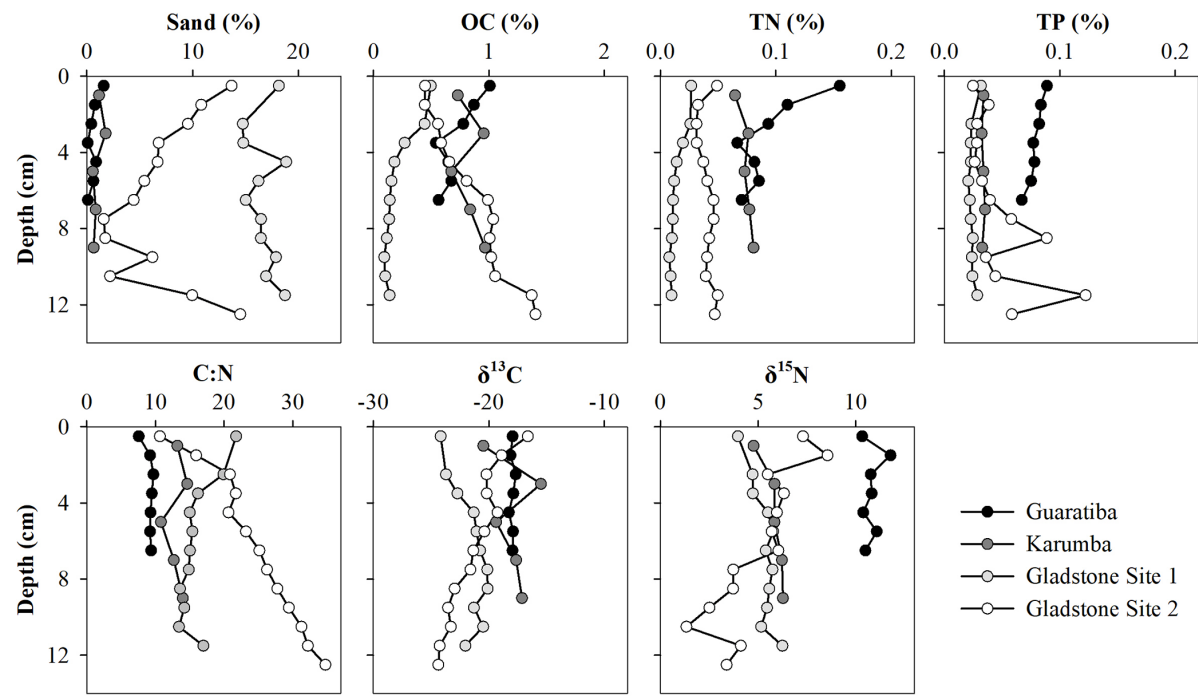

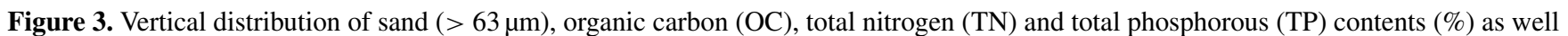
as $\delta^{13} \mathrm{C}, \delta^{15} \mathrm{~N}$ and molar $\mathrm{C}: \mathrm{N}$ ratios of the four hypersaline tidal flat sediment cores.

\section{4 $\mathrm{CO}_{2}$ fluxes at the air-sediment interface}

Median ( \pm SE) hourly $\mathrm{CO}_{2}$ fluxes measured at the airsediment interface varied with HTF location and type of measurement (light vs. dark) (Fig. 5). Median light $\mathrm{CO}_{2}$ values were $-2.1( \pm 4.1), 38.2( \pm 0.0), 13.7( \pm 1.9)$ and $29.3( \pm 2.1) \mathrm{mg} \mathrm{Cm}^{-2} \mathrm{~h}^{-1}$ for the Brazilian (Guaratiba) and Australian (Karumba, Gladstone Site 1 and Gladstone Site 2) HTFs, respectively (Fig. 5). Median $\mathrm{CO}_{2}$ fluxes in the dark chambers were significantly higher than those estimated in the light chambers (Mann-Whitney test; $p<0.05)$, i.e. $2.1( \pm 1.0), 39.6( \pm 9.2), 45.7( \pm 4.5)$ and $34.6( \pm 3.1) \mathrm{mg} \mathrm{Cm}^{-2} \mathrm{~h}^{-1}$ for Guaratiba, Karumba, Gladstone Site 1 and Gladstone Site 2, respectively (Fig. 5). In Brazil, significantly higher $\mathrm{CO}_{2}$ uptake rates (median $\pm \mathrm{SE}$ ) were recorded in the light chambers during the dry season compared to the wet season $(-3.0 \pm 1.3$ and $48.9 \pm$ $7.2 \mathrm{mg} \mathrm{Cm}^{-2} \mathrm{~h}^{-1}$, respectively; Mann-Whitney; $\left.p<0.05\right)$.

\section{Discussion}

\section{1 $\mathrm{C}, \mathrm{N}$ and $\mathrm{P}$ burial in HTFs versus vegetated blue carbon ecosystems}

Considerable differences in OC burial rates between the two Gladstone sites were observed in this study. The likely difference between sites is due to the tidal area of each site; i.e. upper vs. lower tidal areas are expected to accumulate carbon at different rates (Sanders et al., 2014). By averaging the sediment burial rates on a centennial scale (i.e. entire core) of the four sediment cores across all the study sites, we estimate that HTF ecosystems accumulate OC, TN and TP at rates of $21( \pm 6), 1.7( \pm 0.3)$ and $1.4( \pm 0.3) \mathrm{g} \mathrm{m}^{-2} \mathrm{yr}^{-1}$, respectively. These centennial-scale averages reduce short-term variations allowing comparisons with saltmarsh, mangrove forests and seagrass beds which have been studied extensively using similar methodologies and timeframes (McLeod et al., 2011). The average OC accumulation rates in HTF sys- 
Table 2. Mean ( \pm standard error) $\sim 50$-year organic carbon $(\mathrm{OC})$, total nitrogen $(\mathrm{TN})$ and total phosphorus $(\mathrm{TP})$ burial rates in the four hypersaline tidal flat sediment cores. Means are based on one core per site.

\begin{tabular}{lrrr}
\hline Study site & $\mathrm{OC}\left(\mathrm{g} \mathrm{m}^{-2} \mathrm{yr}^{-1}\right)$ & $\mathrm{TN}\left(\mathrm{g} \mathrm{m}^{-2} \mathrm{yr}^{-1}\right)$ & $\mathrm{TP}\left(\mathrm{g} \mathrm{m}^{-2} \mathrm{yr}^{-1}\right)$ \\
\hline Guaratiba & $17.8 \pm 0.8$ & $2.3 \pm 0.2$ & $2.0 \pm 0.1$ \\
Karumba & $31.7 \pm 4.3$ & $2.8 \pm 0.3$ & $1.3 \pm 0.1$ \\
Gladstone Site 1 & $11.3 \pm 2.1$ & $0.8 \pm 0.1$ & $1.4 \pm 0.0$ \\
Gladstone Site 2 & $25.2 \pm 2.9$ & $1.2 \pm 0.1$ & $1.4 \pm 0.3$ \\
\hline
\end{tabular}

tems were $\sim 12-, \sim 8$ - and $\sim 7$-fold lower than the global averages reported for saltmarsh $\left(245 \pm 26 \mathrm{~g} \mathrm{~m}^{-2} \mathrm{yr}^{-1}\right.$; Ouyang and Lee, 2014), mangrove forests $\left(163 \pm 40 \mathrm{~g} \mathrm{~m}^{-2} \mathrm{yr}^{-1}\right.$; Breithaupt et al., 2012) and seagrasses $\left(138 \pm 38 \mathrm{~g} \mathrm{~m}^{-2} \mathrm{yr}^{-1}\right.$; McLeod et al., 2011), respectively. These lower burial rates may be related to the lower organic matter supply (including no contribution from below-ground productivity) and/or lower sediment accretion rates than the traditional blue carbon systems. Furthermore, the reduced structural complexity and ability of the microalgae to trap sediments, the lower primary production rates, the lack of underground root protection, and the fact that microalgae organic material is more labile can explain the lower burial and sediment accretion rates of HTFs than those of traditional, vegetated blue carbon systems.

Hypersaline tidal flats can be a significant source of nutrient export to adjacent ecosystems which may potentially fuel primary productivity in nutrient-limited receiving marine ecosystems (Lovelock et al., 2010; Burford et al., 2016). Here, we find that these HTF ecosystems are also sites for the long-term storage of nitrogen and phosphorus (Table 2). The high TP burial rates observed compared to TN are likely due to the lack of anthropogenic nitrogen inputs observed in other systems. Although the average $\mathrm{TN}$ accumulation rates reported here $\left(1.7 \pm 0.3 \mathrm{~g} \mathrm{~m}^{-2} \mathrm{yr}^{-1}\right)$ were also relatively low when compared to mangrove sediments (12.5 $\pm 1.9 \mathrm{~g} \mathrm{~m}^{-2} \mathrm{yr}^{-1}$; Breithaupt et al., 2014), the average TP accumulation rates in both Australian pristine $\left(1.4 \pm 0.3 \mathrm{~g} \mathrm{~m}^{-2} \mathrm{yr}^{-1}\right)$ and Brazilian eutrophic (2.0 \pm $0.1 \mathrm{~g} \mathrm{~m}^{-2} \mathrm{yr}^{-1}$ ) HTFs were higher than conserved mangrove sites with little anthropogenic nutrient discharges $(0.5 \pm$ $0.2 \mathrm{~g} \mathrm{~m}^{-2} \mathrm{yr}^{-1}$; Breithaupt et al., 2014). However, the HTF TP accumulation rates were not as high as those found in anthropogenically disturbed mangrove sites such as the heavily urbanised Jiulong River estuary, China, with TP accumulation rates reaching $48.1 \mathrm{~g} \mathrm{~m}^{-2} \mathrm{yr}^{-1}$ (Alongi et al., 2005). Anthropogenic activities such as urbanisation and major industrial developments drive degradation and increased primary production in mangrove forests (Sanders et al., 2014). Nutrients such as iron and phosphorus may be limiting to mangrove growth (Alongi, 2010; Reef et al., 2010), and those forests receiving high nutrient loads from highly concentrated anthropogenic nutrient discharges accumulate OC, TN and $\mathrm{TP}$ at rates much higher than those from the undisturbed

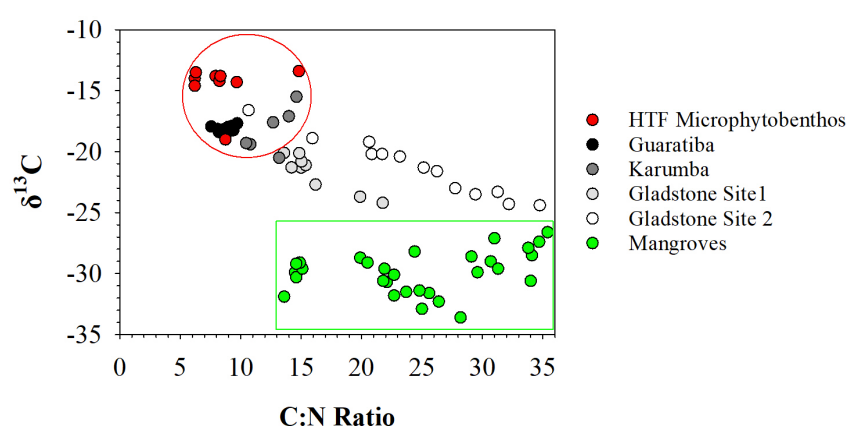

Figure 4. Distribution of $\delta^{13} \mathrm{C}$ vs. $\mathrm{C}: \mathrm{N}$ molar ratio in the four hypersaline tidal flat sediment cores. Endmember values were taken from HTF surface microphytobenthos and nearby mangrove vegetation.

mangrove (Sanders et al., 2014). Nevertheless, the nitrogen and phosphorus burial in HTFs as shown here over long periods of time may play an important role in nutrient sequestration from other coastal anthropogenic activities, e.g. shrimp farming activities (Ashton, 2008; Marchand et al., 2011).

By upscaling the average $\mathrm{OC}, \mathrm{TN}$ and TP accumulation results for the past century in this study to the regional areas of HTFs, we can provide a first-order estimate of the amount of OC, TN and TP being stored annually in these HTFs. Ridd and Stieglitz (2002) identify the areal extent of both HTFs and mangrove forests for five estuaries in Queensland, Australia, with the HTFs identified as having a $\sim 10$-fold higher areal extent $\left(279 \mathrm{~km}^{2}\right)$ than mangrove forests $\left(29 \mathrm{~km}^{2}\right)$ over the five estuaries. In these estuaries alone, HTFs would contribute to the annual accumulation of approximately $5.76 \pm$ $1.57,0.46 \pm 0.09$ and $0.40 \pm 0.08 \mathrm{Gg} \mathrm{yr}^{-1}$ of OC, TN and TP, respectively, which is similar to the contribution of mangrove forests $\left(4.73 \pm 1.16,0.36 \pm 0.06\right.$ and $0.26 \pm 0.03 \mathrm{Gg} \mathrm{yr}^{-1}$ for $\mathrm{OC}, \mathrm{TN}$ and TP, respectively) when based on global average accumulation rates (Breithaupt et al., 2012, 2014). In contrast to Australia, the mangrove forests of Guaratiba $\left(20.9 \mathrm{~km}^{2}\right)$ have been identified to have a $\sim 3$-fold higher area than local HTFs $\left(7.4 \mathrm{~km}^{2}\right.$ ) (Soares et al., 2017), resulting in annual OC, $\mathrm{TN}$ and TP accumulation in HTFs $(0.15 \pm 0.04,0.01 \pm 0.00$ and $0.01 \pm 0.00 \mathrm{Gg} \mathrm{yr}^{-1}$, respectively) equivalent to $4 \%-$ $6 \%$ of those estimated for mangrove forests $(3.41 \pm 0.84$, $0.26 \pm 0.04$ and $0.19 \pm 0.02 \mathrm{Gg} \mathrm{yr}^{-1}$ for OC, TN and TP, re- 

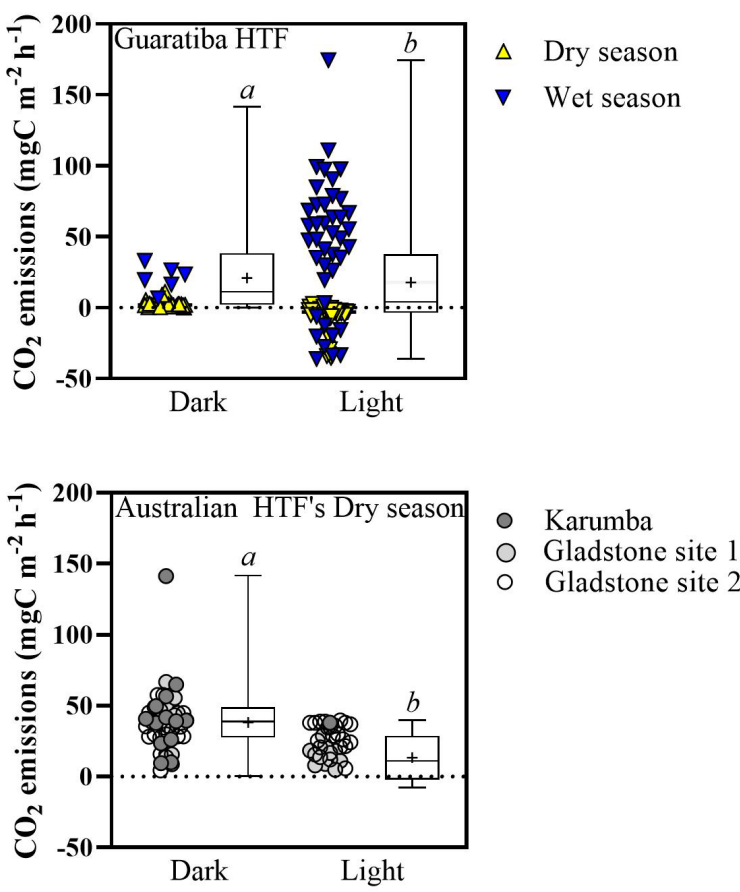

Figure 5. Median air-sediment $\mathrm{CO}_{2}$ fluxes $\left(\mathrm{mg} \mathrm{Cm}^{-2} \mathrm{~h}^{-1}\right)$ from hypersaline tidal flat sediments of Guaritiba, Brazil (dry season represented by yellow triangles $-n=44$ for dark chambers and $n=53$ for light chambers; wet season represented by blue triangles $-n=6$ for dark chambers and $n=41$ for light chambers), and Australia (Gladstone sites represented by light grey and white circles $-n=33$ for dark chambers and $n=31$ for light chambers; Karumba site represented by dark grey circles $-n=13$ for dark chambers and $n=1$ for light chambers). Negative values represent net $\mathrm{CO}_{2}$ influx to sediments, while positive values represent net $\mathrm{CO}_{2}$ emission to the atmosphere. Average values are represented by crosses, and error bars denote minimum to maximum. Different letters indicate significant differences (Mann-Whitney; $p<0.05$ ).

spectively) when based on global average accumulation rates (Breithaupt et al., 2012, 2014).

Our estimates suggest HTFs are capable of long-term storage of OC, TN and TP and, given their large areal extent, have the potential to store as much OC, TN and TP as traditional coastal blue carbon systems in arid regions such as Queensland, Australia. To improve these estimates, there is clearly a need to determine carbon and nutrient accumulation rates from additional coastal HTFs and assess their areal cover in Australia, Brazil and elsewhere. Furthermore, microphytobenthos also exist in the arid or semi-arid areas near saltmarshes, as well as in the lower intertidal flats inundated daily, which are often areas greater in extent than vegetated areas and may contribute to blue carbon burial.

\subsection{Organic matter source}

Microphytobenthos associated with coastal HTF ecosystems were an important source of OM accumulation in each of the sediment profiles. Microscopic examinations in previous studies have identified the cyanobacteria Oscillatoria spp., Lyngbya spp., Microcoleus spp. and Phormidium spp. as the dominant microphytobenthos in HTF ecosystems (Adame et al., 2012; Burford et al., 2016; Masuda and Enrich-Prast, 2016; Bento et al., 2017). These microphytobenthos are likely to be the important species contributing to the accumulation of OM, particularly in Guaratiba and Karumba where the $\delta^{13} \mathrm{C}$ and $\mathrm{C}: \mathrm{N}$ ratio values were consistently similar to those of the HTF microphytobenthos endmember values (Fig. 4). Therefore, we suggest that microphytobenthos were the dominate source of OM accumulating in the sedimentary substrates during the past century.

In contrast to the Guaratiba and Karumba profiles, the considerable spread in $\delta^{13} \mathrm{C}$ and molar $\mathrm{C}: \mathrm{N}$ ratio values along the Gladstone sedimentary profiles suggests the OM accumulation inputs are from a combination of microphytobenthos and mangrove material (Fig. 4). These results are not surprising given the vast areal extent of mangrove systems in Gladstone Harbour and their close proximity to the HTFs. Effective $\mathrm{N}$ consumption in coastal wetland sediments (Wadnerkar et al., 2019) may increase overall sedimentary C : N ratios. Sedimentary $\mathrm{N}$ and the relatively higher $\delta^{15} \mathrm{~N}$ values observed in the Guaratiba HTF sediments (Fig. 3) may be indicative of eutrophication (Sanders et al., 2014). Indeed, wastewater inputs typically have elevated $\delta^{15} \mathrm{~N}$ values due to elevated nitrogen cycling including denitrification (Costanzo et al., 2005). Anthropogenic wastewater inputs high in $\mathrm{N}$ and $\mathrm{P}$ loads are also of growing concern across the globe, particularly in HTF areas near shrimp farming (Ashton, 2008; Marchand et al., 2011). While there are no shrimp farms near our study sites, the release of high $\mathrm{N}$ and $\mathrm{P}$ loads may drive eutrophication of adjacent coastal areas (Ashton, 2008; Marchand et al., 2011) and modify carbon burial rates (Sanders et al., 2014). In addition to the increase in the $\mathrm{N}$ and $\mathrm{P}$ release, shrimp farms would drive a reduction in the HTF area that may remove $\mathrm{N}$ and $\mathrm{P}$.

\section{3 $\mathrm{CO}_{2}$ fluxes at the air-sediment interface}

The great variability in air-saltpan $\mathrm{CO}_{2}$ fluxes here suggests a highly dynamic and productive metabolism along the HTFs. The oligotrophic Gladstone sites were net sources of $\mathrm{CO}_{2}$ to the atmosphere in the dry season $(0.72 \pm$ $0.01 \mathrm{~g} \mathrm{C} \mathrm{m}^{-2} \mathrm{~d}^{-1}$ ), while the eutrophic Guaratiba HTF experienced net $\mathrm{CO}_{2}$ uptake and was a source in the dry and rainy season $\left(-0.03 \pm 0.01\right.$ and $0.71 \pm 0.22 \mathrm{~g} \mathrm{C} \mathrm{m}^{-2} \mathrm{~d}^{-1}$, respectively). These estimates of net seasonal fluxes of $\mathrm{CO}_{2}$ contribute to reducing the scarcity of studies quantifying this gas exchange at the air-sediment interface in HTFs (Table 3). The net $\mathrm{CO}_{2}$ source observed during rainy seasons compared to the net influx during dry seasons in Brazil (MannWhitney; $p<0.05$ ) may be attributed to higher temperature and cloud cover over sampling days in the rainy summer than that over sampling days in the dry winter. Previous evidence 
Table 3. Mean sediment organic carbon content $(\%)$ and $\mathrm{CO}_{2}$ fluxes $\left(\mathrm{mg} \mathrm{Cm}^{-2} \mathrm{~h}^{-1}\right)$ at the air-sediment interface in hypersaline tidal flat sediments reported in the literature. Values are means \pm standard error unless otherwise stated.

\begin{tabular}{|c|c|c|c|c|}
\hline Location & $\begin{array}{r}\text { Air-sediment } \\
\mathrm{CO}_{2} \text { fluxes (light) } \\
\left(\mathrm{mg} \mathrm{Cm}^{-2} \mathrm{~h}^{-1}\right)\end{array}$ & $\begin{array}{r}\text { Air-sediment } \\
\mathrm{CO}_{2} \text { fluxes (dark) } \\
\left(\mathrm{mg} \mathrm{Cm}^{-2} \mathrm{~h}^{-1}\right)\end{array}$ & $\begin{array}{l}\text { Sediment organic } \\
\text { carbon content }(\%)\end{array}$ & Reference \\
\hline New Caledonia & $20.4 \pm 3.2$ & $20.0 \pm 3.3$ & $1.6 \pm 0.2^{\mathrm{d}}$ & Leopold et al. (2013) \\
\hline Guaratiba, Brazil & & & & \\
\hline Dry season & $-6.7 \pm 1.3$ & $2.3 \pm 0.3$ & $0.6 \pm 0.0$ & This study \\
\hline Wet season & $44.2 \pm 7.2$ & $20.9 \pm 3.7$ & $0.6 \pm 0.0$ & This study \\
\hline Guaratiba, Brazil & $-5.3 \pm 3.2^{\mathrm{b}}$ & $4.8 \pm 3.6^{\mathrm{b}}$ & NA & Bento et al. (2017) \\
\hline Gladstone, Australia & $24.3 \pm 2.0$ & $36.5 \pm 2.7$ & $0.5 \pm 0.1$ & This study \\
\hline Karumba, Australia & $38.2 \pm 0.0$ & $44.8 \pm 9.2$ & $0.8 \pm 0.1$ & This study \\
\hline Karumba, Australia & $14.5 \pm 12.2^{\mathrm{a}, \mathrm{b}}$ & $0.9 \pm 0.5^{\mathrm{a}, \mathrm{b}}$ & NA & Burford et al. (2016) \\
\hline Exmouth Gulf, Australia & $64.8 \pm 7.4^{\mathrm{a}}$ & $40.2 \pm 3.7^{\mathrm{a}}$ & 0.7 & Lovelock et al. (2010) \\
\hline Arabian Gulf, United Arab Emirates & \multicolumn{2}{|c|}{$38.0 \pm 15.1^{\mathrm{b}, \mathrm{e}}$} & $1.6 \pm 0.7^{\mathrm{b}}$ & Schile et al. (2017) \\
\hline Murcia, Spain & NA & NA & $5.2 \pm 0.5$ & Conesa et al. (2011) \\
\hline Tunisia, Africa & NA & NA & $0.6 \pm 0.1$ & Chairi et al. (2010) \\
\hline Ceará, Brazil & NA & NA & $0.5 \pm 0.3$ & Albuquerque et al. (2014) \\
\hline Ceará, Brazil & NA & NA & $0.7 \pm 0.8$ & Albuquerque et al. (2013) \\
\hline Bahia, Brazil & NA & NA & $0.7 \pm 0.1^{\mathrm{c}}$ & Albuquerque et al. (2013) \\
\hline Teremba Bay, New Caledonia & NA & NA & $5.9 \pm 1.2^{\mathrm{b}}$ & Marchand et al. (2011) \\
\hline Tampa Bay, Florida & NA & NA & $0.7 \pm 0.5$ & Radabaugh et al. (2018) \\
\hline
\end{tabular}

${ }^{a}$ Fluxes calculated from measurements of oxygen $\left(\mathrm{O}_{2}\right)$ assuming a molar $\mathrm{CO}_{2}: \mathrm{O}_{2}$ ratio of $1: 1{ }^{\mathrm{b}}$ Values from figures were estimated using WebPlotDigitizer (https://automeris.io/WebPlotDigitizer/, last access: 1 June 2020). ${ }^{\mathrm{c}}$ Organic carbon value $=$ organic matter $/ 1.724 .{ }^{\mathrm{d}}$ Organic carbon value is $95 \%$ of total carbon value.

e Study did not clarify if $\mathrm{CO}_{2}$ flux was measured in a light or dark chamber.

indicates that the light attenuation by clouds may reduce microphytobenthos photosynthetic activity (Barnett et al., 2020), while warmer sampling conditions on average \pm SE of $26.7 \pm 0.02$ and $21.5 \pm 0.02{ }^{\circ} \mathrm{C}$ during the wet and dry season, respectively, may stimulate heterotrophy in tidal flat systems (Laviale et al., 2015; Lin et al., 2020). The $\mathrm{CO}_{2}$ source to the atmosphere found during the rainy summer still contrasted with previous evidence in the same Brazilian HTF on an enhanced $\mathrm{CO}_{2}$ sink after rain events in winter (Bento et al., 2017), suggesting that factors other than the occurrence of precipitation (e.g. rainfall duration and intensity) may cause the dynamic short-term changes in microphytobenthic production. In addition, higher values of air-saltpan $\mathrm{CO}_{2}$ influx in the Brazilian HTF than in the Australian HTFs during similar sunnier periods may be attributed to more eutrophic conditions, which could stimulate microphytobenthic production in saltpan sediments (Xie et al., 2019). These findings highlight the high temporal variability and the need for future seasonal sampling due to the short-term shifts in air-saltpan $\mathrm{CO}_{2}$ exchange, specifically considering the potential net atmospheric $\mathrm{CO}_{2}$ sink in HTFs as indicated by the autochthonous OM found in the sedimentary profiles. As such, gaining a clearer understanding of the drivers of net primary production in HTFs during changing climatic and anthropogenic conditions is critical to determining their global relevance as atmospheric carbon sinks.

\subsection{Can HTFs be considered "blue carbon" systems?}

While much of the research on blue carbon systems continues to focus on mangrove forests, tidal marshes, and seagrass meadows, there are suggestions to consider other ecosystems in the blue carbon framework (Raven, 2018; TrevathanTackett et al., 2015; Lovelock and Duarte, 2019). Tidally influenced freshwater forests, marine macroalgae and kelp beds, and HTFs, for instance, are all ecosystems where blue carbon stocks and sequestration rates may be conceptually equivalent to conventional blue carbon systems (Raven, 2018; Krause-Jensen et al., 2018; Krauss et al., 2018; Lovelock and Duarte, 2019).

Lovelock and Duarte (2019) discuss several key assessment criteria for the inclusion of an ecosystem in the blue carbon framework. First, an ecosystem needs to be capable of long-term storage of $\mathrm{CO}_{2}$ resulting in significant greenhouse gas (GHG) removal from the atmosphere. The results from this study indicate that HTF ecosystems are capable of long-term storage of fixed $\mathrm{CO}_{2}$ at rates averaging $21 \pm 6 \mathrm{~g} \mathrm{C} \mathrm{m}^{-2} \mathrm{yr}^{-1}$. Given that HTFs are extensively distributed in coastal areas showing freshwater deficit such as in northern Australia and Brazil, the scale of $\mathrm{CO}_{2}$ removal can be significant and comparable to traditional blue carbon systems in some key arid regions. While this study demonstrates carbon burial in three HTF systems, accurate estimates of the magnitude of this carbon sink on national or global scales will require further studies and improved areal estimates. 
The second consideration for inclusion into the blue carbon framework is that management of an ecosystem is possible. Management should maintain or enhance carbon and nitrogen stocks and thereby reduce GHG emissions (Lovelock and Duarte, 2019). Over the past few decades, HTFs have experienced large-scale destruction and degradation on a global scale as a result of anthropogenic pressures such as urban and agricultural development (Ashton, 2008; Halpern et al., 2008; Martinez-Porchas and Martinez-Cordova, 2012) which may ultimately lead to large-scale release of $\mathrm{CO}_{2}$ to the atmosphere. Local, national and/or international management actions, therefore, have the potential to reduce and possibly revert these losses and destruction, thereby maintaining or even enhancing $\mathrm{C}$ sequestration similarly to adjacent mangroves and saltmarshes. These management practices include regulating urban development or the construction of shrimp farming to prevent HTF ecosystem decline (Halpern et al., 2008; Martinez-Porchas and Martinez-Cordova, 2012). Moreover, current frameworks and management strategies in place for coastal vegetated ecosystems have the potential to incorporate HTFs given their close association. Therefore, we suggest that HTF ecosystems can be classified as blue carbon systems and should be included in global management and mitigation policies and are likely to be important contributors on regional scales.

\section{Conclusions}

The investigated HTF ecosystems accumulated significant amounts of OC, TN and TP during the previous century. Although these accumulation rates are lower than those in other vegetated blue carbon systems per unit area, a substantial amount of carbon and nutrients are sequestered in HTFs considering their extensive global areal extent and should not be overlooked. Stable isotope analysis along with the molar $\mathrm{C}: \mathrm{N}$ ratios indicates that the microphytobenthos associated with these HTFs are an important source of the organic material accumulated along the sediment columns of these systems. To improve the robustness of our observations, there is a need to determine carbon and nutrient accumulation rates and $\mathrm{CO}_{2}$ fluxes from additional coastal HTFs and to determine a more precise areal estimate of HTFs in Australia, Brazil and other parts of the world. However, our initial data imply that these coastal HTF ecosystems fit the definition of blue carbon systems and could be included in global and regional management and mitigation polices.

Data availability. The data used in this research are available in the tables and figures.

Author contributions. DRB, HRM and CJS designed and obtained funding for this work. DRB, CJS, HRM, RBP, DTM and LSM con- tributed to acquisition of data and contributed to the analysis and interpretation of data. All of the authors made contributions to the drafting of the article and revisions critical for important intellectual content. All authors gave the final approval of the version to be published.

Competing interests. The authors declare that they have no conflict of interest.

Acknowledgements. Field and laboratory investigations were funded by the Australian Research Council (DE160100443, DP180101285 and LE140100083). Humberto Marrota and Roberta B. Peixoto were funded by Coordenação de Aperfeiçoamento de Pessoal de Nível Superior (CAPES - Código 001). Humberto Marrota was awarded CNPq Research Productivity and FAPERJ Young Scientist of Rio de Janeiro State fellowships. Alexander Pérez is supported by the Fondo Nacional de Desarrollo Cientıfico, Tecnológico y de Innovación Tecnológica (FONDECYT - Peru) through the Magnet Program (grant no. 007-2017-FONDECYT) and the Incorporación de Investigadores programme (grant no. E038-2019-02-FONDECYT-BM).

Financial support. This research has been supported by the Australian Research Council (grant nos. DE160100443, DP180101285 and LE140100083).

Review statement. This paper was edited by Tina Treude and reviewed by Begy Robert-Csaba and one anonymous referee.

\section{References}

Adame, M. F., Reef, R., Grinham, A., Holmes, G., and Lovelock, C. E.: Nutrient exchange of extensive cyanobacterial mats in an arid subtropical wetland, Mar. Freshw. Res., 63, 457-467, 2012.

Albuquerque, A. G. B. M., Ferreira, T. O., Cabral, R. L., Nóbrega, G. N., Romero, R. E., Meireles, A. J. d. A., and Otero, X. L.: Hypersaline tidal flats (apicum ecosystems): the weak link in the tropical wetlands chain, Environ. Rev., 22, 99-109, 2013.

Albuquerque, A., Ferreira, T., Nóbrega, G., Romero, R., Júnior, V. S., Meireles, A., and Otero, X.: Soil genesis on hypersaline tidal flats (apicum ecosystem) in a tropical semi-arid estuary (Ceará, Brazil), Soil Res., 52, 140-154, 2014.

Alongi, D. M.: Mangrove forests: resilience, protection from tsunamis, and responses to global climate change, Estuar. Coast. Shelf Sci., 76, 1-13, 2008.

Alongi, D. M.: Dissolved iron supply limits early growth of estuarine mangroves, Ecology, 91, 3229-3241, 2010.

Alongi, D., Pfitzner, J., Trott, L., Tirendi, F., Dixon, P., and Klumpp, D.: Rapid sediment accumulation and microbial mineralization in forests of the mangrove Kandelia candel in the Jiulongjiang Estuary, China, Estuar. Coast. Shelf Sci., 63, 605-618, 2005.

Appleby, P. G. and Oldfield, F.: Application of lead-210 to sedimentation studies, in: Uranium Series Disequilibrium: Appli- 
cation to Earth, Marine and Environmental Science, edited by: Ivanovich, M., and Harmon, S., Oxford Science Publications, 731-783, 1992.

Ashton, E. C.: The impact of shrimp farming on mangrove ecosystems, CAB Rev.: Persp. Agr. Vet. Sci. Nut. Nat. Res., 3, https://doi.org/10.1079/PAVSNNR20083003, 2008.

Barnett, A., Méléder, V., Dupuy, C., and Lavaud, J.: The vertical migratory rhythm of intertidal microphytobenthos in sediment depends on the light photoperiod, intensity, and spectrum: Evidence for a positive effect of blue wavelengths, Front. Mar. Sci., 7, https://doi.org/10.3389/fmars.2020.00212, 2020.

Bento, L., Masuda, L. S. M., Peixoto, R. B., and Enrich-Prast, A.: Regulation in the metabolism and community structure of a tropical salt flat after rainfall, J. Coast. Res., 33, 304-308, 2017.

Breithaupt, J. L., Smoak, J. M., Smith, T. J., Sanders, C. J., and Hoare, A.: Organic carbon burial rates in mangrove sediments: Strengthening the global budget, Global Biogeochem. Cy., 26, https://doi.org/10.1002/2014JG002715, 2012.

Breithaupt, J. L., Smoak, J. M., Smith, T. J., and Sanders, C. J.: Temporal variability of carbon and nutrient burial, sediment accretion, and mass accumulation over the past century in a carbonate platform mangrove forest of the Florida Everglades, J. Geophys. Res.-Biogeo., 119, https://doi.org/10.1002/2014JG002715, 2014.

Bureau of Meteorology: Climate statistics for Australian locations, available at: http://www.bom.gov.au/climate/averages/ tables/cw_029028.shtml (last access: 12 December 2019), 2019.

Burford, M., Valdez, D., Curwen, G., Faggotter, S., Ward, D., and Brien, K. O.: Inundation of saline supratidal mudflats provides an important source of carbon and nutrients in an aquatic system, Mar. Ecol. Prog. Ser., 545, 21-33, 2016.

Chairi, R., Derenne, S., Abdeljaoued, S., and Largeau, C.: Sediment cores representative of contrasting environments in salt flats of the Moknine continental sabkha (Eastern Tunisia): sedimentology, bulk features of organic matter, alkane sources and alteration, Org. Geochem., 41, 637-652, 2010.

Conesa, H., María-Cervantes, A., Álvarez-Rogel, J., and GonzálezAlcaraz, M: Influence of soil properties on trace element availability and plant accumulation in a Mediterranean salt marsh polluted by mining wastes: implications for phytomanagement, Sci. Total Environ., 409, 4470-4479, 2011.

Conrad, S. R., Santos, I. R., White, S., and Sanders, C. J.: Nutrient and trace metal fluxes into estuarine sediments linked to historical and expanding agricultural activity (Hearnes Lake, Australia), Estuar. Coasts, 42, 944-957, 2019.

Costanzo, S. D., Udy, J., Longstaff, B., and Jones, A.: Using nitrogen stable isotope ratios $\left(\delta^{15} \mathrm{~N}\right)$ of macroalgae to determine the effectiveness of sewage upgrades: changes in the extent of sewage plumes over four years in Moreton Bay, Australia, Mar. Pollut. Bull., 51, 212-217, 2005.

Estevam, R. M. E.: Os manguezais de Guaratiba Frente às mudanças climáticas globais: análise da influência da variabilidade climática sobre a dinâmica de comunidades pioneiras, Universidade do Estado do Rio de Janeiro, Programa de Pós-Graduação em Meio Ambiente, 99, 2019.

Estrada, G. C. D., Soares, M. L. G., de Oliveira Chaves, F., and Cavalcanti, V. F.: Analysis of the structural variability of mangrove forests through the physiographic types approach, Aquat. Bot., 111, 135-143, 2013.
Halpern, B. S., Walbridge, S., Selkoe, K. A., Kappel, C. V., Micheli, F., D'agrosa, C., Bruno, J. F., Casey, K. S., Ebert, C., and Fox, H. E.: A global map of human impact on marine ecosystems, Science, 319, 948-952, 2008.

Kelleway, J. J., Cavanaugh, K., Rogers, K., Feller, I. C., Ens, E., Doughty, C., and Saintilan, N.: Review of the ecosystem service implications of mangrove encroachment into salt marshes, Global Change Biol., 23, 3967-3983, 2017.

Krause-Jensen, D., Lavery, P., Serrano, O., Marbà, N., Masque, P., and Duarte, C. M.: Sequestration of macroalgal carbon: the elephant in the Blue Carbon room, Biol. Lett., 14, https://doi.org/10.1098/rsbl.2018.0236, 2018.

Krauss, K. W., Noe, G. B., Duberstein, J. A., Conner, W. H., Stagg, C. L., Cormier, N., Jones, M. C., Bernhardt, C. E., Graeme Lockaby, B., and From, A. S.: The role of the upper tidal estuary in wetland blue carbon storage and flux, Global Biogeochem. Cy., 32, 817-839, 2018.

Laviale, M., Barnett, A., Ezequiel, J., Lepetit, B., Frankenbach, S., Méléder, V., Serôdio, J., and Lavaud, J.: Response of intertidal benthic microalgal biofilms to a coupled light-temperature stress: evidence for latitudinal adaptation along the Atlantic coast of Southern Europe, Environ. Microbiol., 17, 3662-3677, 2015.

Leopold, A., Marchand, C., Deborde, J., Chaduteau, C., and Allenbach, M.: Influence of mangrove zonation on $\mathrm{CO}_{2}$ fluxes at the sediment-air interface (New Caledonia), Geoderma, 202-203, 62-70, 2013.

Leopold, A., Marchand, C., Deborde, J., and Allenbach, M.: Temporal variability of $\mathrm{CO}_{2}$ fluxes at the sediment-air interface in mangroves (New Caledonia), Sci. Total Environ., 502, 617-626, 2015.

Lin, W. J., Wu, J., and Lin, H. J.: Contribution of unvegetated tidal flats to coastal carbon flux, Global Change Biol., 26, 3443-3454, 2020.

Lovelock, C. E.: Soil respiration and belowground carbon allocation in mangrove forests, Ecosystems, 11, 342-354, 2008.

Lovelock, C. E. and Duarte, C. M.: Dimensions of Blue Carbon and emerging perspectives, Biol. Lett., 15, 2019.

Lovelock, C. E., Grinham, A., Adame, M. F., and Penrose, H. M.: Elemental composition and productivity of cyanobacterial mats in an arid zone estuary in north Western Australia, Wetl. Ecol. Manag., 18, 37-47, 2010.

Macreadie, P. I., Anton, A., Raven, J. A., Beaumont, N., Connolly, R. M., Friess, D. A., Kelleway, J. J., Kennedy, H., Kuwae, T., and Lavery, P. S.: The future of Blue Carbon science, Nat. Commun., 10, 1-13, 2019.

Marchand, C., Lallier-Vergès, E., and Allenbach, M.: Redox conditions and heavy metals distribution in mangrove forests receiving effluents from shrimp farms (Teremba Bay, New Caledonia), J. Soils Sediments., 11, 529-541, 2011.

Martinez-Porchas, M. and Martinez-Cordova, L. R.: World aquaculture: Environmental impacts and troubleshooting alternatives, Sci. World J., 9, https://doi.org/10.1100/2012/389623, 2012.

Masuda, L. and Enrich-Prast, A.: Benthic microalgae community response to flooding in a tropical salt flat, Braz. J. Biol., 76, 577582, 2016.

McLeod, E., Chmura, G. L., Bouillon, S., Salm, R., Björk, M., Duarte, C. M., Lovelock, C. E., Schlesinger, W. H., and Silliman, B. R.: A blueprint for blue carbon: Toward an improved under- 
standing of the role of vegetated coastal habitats in sequestering $\mathrm{CO}_{2}$, Front. Ecol. Environ., 9, 552-560, 2011.

Ouyang, X. and Lee, S. Y.: Updated estimates of carbon accumulation rates in coastal marsh sediments, Biogeosciences, 11, 50575071, https://doi.org/10.5194/bg-11-5057-2014, 2014.

Paerl, H. W., Pinckney, J. L., and Steppe, T. F.: Cyanobacterialbacterial mat consortia: Examining the functional unit of microbial survival and growth in extreme environments, Environ. Microbiol., 2, 11-26, 2000.

Radabaugh, K. R., Moyer, R. P., Chappel, A. R., Powell, C. E., Bociu, I., Clark, B. C., and Smoak, J. M.: Coastal blue carbon assessment of mangroves, salt marshes, and salt barrens in Tampa Bay, Florida, USA, Estuar. Coasts., 41, 1496-1510, 2018.

Raven, J.: Blue carbon: past, present and future, with emphasis on macroalgae, Biol. Lett., 14, https://doi.org/10.1098/rsbl.2018.0336, 2018.

Ravichandran, M., Baskaran, M., Santschi, P. H., and Bianchi, T. S.: Geochronology of sediments in the Sabine-Neches estuary, Texas, USA, Chem. Geol., 125, 291-306, 1995.

Reef, R., Feller, I. C., and Lovelock, C. E.: Nutrition of mangroves, Tree Physiol., 30, 1148-1160, 2010.

Rezende, C., Pfeiffer, W., Martinelli, L., Tsamakis, E., Hedges, J., and Keil, R.: Lignin phenols used to infer organic matter sources to Sepetiba Bay - RJ, Brasil, Estuar. Coast. Shelf Sci., 87, 479486, 2010.

Ridd, P. and Stieglitz, T.: Dry season salinity changes in arid estuaries fringed by mangroves and saltflats, Estuar. Coast. Shelf Sci., 54, 1039-1049, 2002.

Rosentreter, J., Maher, D. T., Ho, D., Call, M., Barr, J., and Eyre, B. E.: Spatial and temporal variability of $\mathrm{CO}_{2}$ and $\mathrm{CH}_{4}$ gas transfer velocities and quantification of the $\mathrm{CH}_{4}$ microbubble flux in mangrove dominated estuaries, Limnol. Oceanogr., 62, 561-578, 2017.

Saintilan, N., Wilson, N. C., Rogers, K., Rajkaran, A., and Krauss, K. W.: Mangrove expansion and salt marsh decline at mangrove poleward limits, Global Change Biol., 20, 147-157, 2014.
Sanders, C. J., Eyre, B. E., Santos, I. R., Machado, W., Luiz-Silva, W., Smoak, J. M., Breithaupt, J. L., Ketterer, M. E., Sanders, L., Marotta, H., and Silva-Filho, E.: Elevated rates of organic carbon, nitrogen, and phosphorus accumulation in a highly impacted mangrove wetland, Geophys. Res. Lett., 41, 2475-2480, 2014.

Sanders, C. J., Maher, D. T., Tait, D. R., Williams, D., Holloway, C., Sippo, J. Z., and Santos, I. R.: Are global mangrove carbon stocks driven by rainfall?, J. Geophys. Res.-Biogeo., 121, 26002609, 2016a.

Schile, L. M., Kauffman, J. B., Crooks, S., Fourqurean, J. W., Glavan, J., and Megonigal, J. P.: Limits on carbon sequestration in arid blue carbon ecosystems, Ecol. Appl., 27, 859-874, 2017.

Serrano, O., Lovelock, C. E., Atwood, T. B., et al.: Australian vegetated coastal ecosystems as global hotspots for climate change mitigation. Nat. Commun., 10, 1-10, 2019.

Shen, C., Zhang, C., Xin, P., Kong, J., and Li, L.: Salt dynamics in coastal marshes: Formation of hypersaline zones, Water Resour. Res., 54, 3259-3276, 2018.

Soares, M. L. G., Chaves, F. D. O., Estrada, G. C. D., and Fernandez, V.: Mangrove forests associated with salt flats: A case study from southeast Brazil, Braz. J. Oceanogr., 65, 102-115, 2017.

Trevathan-Tackett, S. M., Kelleway, J., Macreadie, P. I., Beardall, J., Ralph, P., and Bellgrove, A.: Comparison of marine macrophytes for their contributions to blue carbon sequestration, Ecology, 96, 3043-3057, 2015.

Wadnerkar, P. D., Santos, I. R., Looman, I., Sanders, C. J., White, S., Tucker, J. P., and Holloway, C. Significant nitrate attenuation in a mangrove-fringed estuary during a flood-chase experiment, Environ. Pollut., 253, 1000-1008, 2019.

Xie, Y., Wang, L., Liu, X., Li, X., Wang, Y., and Huang, B.: Contrasting responses of intertidal microphytobenthos and phytoplankton biomass and taxonomic composition to the nutrient loads in the Jiulong River Estuary, Phycol. Res., 67, 152-163, 2019. 